\title{
Enterprise Management in the Context of Expanding the Scope of Blockchain Technology
}

\author{
Sergey Verteshev \\ Pskov State University \\ Pskov, Russia \\ president@pskgu.ru
}

\author{
Anton Verteshev \\ Pskov State University \\ Pskov, Russia \\ a_verteshev@mail.ru
}

\author{
Mikhail Voronov \\ Pskov State University \\ Pskov, Russia \\ mivoronov@yandex.ru
}

\begin{abstract}
The method of creating an automated enterprise management system is considered. The method is based on the ideas of the imitation approach and fuzzy mathematics. Real-time enterprise planning is the goal. The method is relevant in the context of setting up the market for goods and services with the expansion of e-commerce. The model of the formation of the plan of the enterprise for the execution of the orders received is considered.
\end{abstract}

Keywords - Blockchain, smart contract, automated system, prompt enterprise management, efficiency indicators, constructive-simulation model, planning randomization.

\section{INTRODUCTION}

On the modern market of goods and services, the manufacturer should not only have and offer a certain product. One of the trends of the modern market is the desire of the enterprise to find a client and lead to a significant negotiation with him, including remotely in real time. Customization of the goods and services market occurs [1]. At the same time, a potential customer is trying to provide itself with more favorable conditions: the price of goods, deadlines and delivery scheme, as well as other components of the services. The interests of the buyer are becoming increasingly important argument in the conditions of exceeding the proposal on the need. The introduction of e-commerce [2], as well as the emergence and development of the technology of the blockchain [3], contributes to solving these tasks

Blockchain is a tool for transferring and storing data. For business cooperation, partners use databases. The process of interaction between business partners is associated with operations in the database, that is, with transactions. All transaction can be performed using Blockchain technology.
Bitcoin, Ethereum, NXT, Side Chans are the most popular platforms operating on the Blockchain principle. They are created mainly for the financial sector. However, Ethereum is a good platform for creating smart contracts [4].

Blockchain and smart contracts technology allow modern enterprises to switch to small-scale production. Such possibilities are very convenient for buyers. However, they create a number of business difficulties. The fact is that each order requires the development of its own unique technology. The company must simultaneously perform a large number of small orders. This requires qualitative changes in the operational planning of the enterprise.

Any enterprise is an open system. Streams of matter, energy and information flow through it. This makes him dependent on the external environment and makes him adapt. A modern enterprise operates in a single economic space. Its dependence on the environment is constantly growing. The success of activities in such conditions depends on an adequate reaction of the enterprise to the market situation, as well as on the ability to predict the development of the situation.

Each new order must take into account the technological capabilities of the enterprise and the availability of resources. There are many orders, they come at a random time. The company needs up-to-date databases for all production components. Databases should contain changing information about all orders, equipment utilization, the maximum allowable lead time for each order, and the availability of financial and other resources at the enterprise. When new orders arrive, tools for adjusting production plans are required. 
Currently, work is underway to create specialized enterprise management systems from a variety of positions. In this aspect, the most interesting is the MES (Manufacturing Execution System) [5]. This is an information and communication system of the enterprise, focused on the management of current production activities in accordance with incoming orders, the requirements of design and technological documentation, the current state of the equipment and pursuing the goal of maximum production efficiency. .. It can be viewed as a link between ERP-systems focused on financial and economic tasks [6] and the operational production activities of an enterprise at the site or production line level. Despite significant advantages, MES systems actively use the calendar planning toolkit, thereby not being suitable for solving the entire complex of online management tasks.

To implement the mechanism of enterprise management in extreme situations, situational centers began to form. The main purpose of their purpose is as follows:

1. Monitoring the status of the management object and its environment;

2. Support for the process of solutions (including on the basis of information and analytical systems and mathematical planning models);

3. Support for operational management in crisis situations.

Undoubtedly, many tasks of situational centers are related to the functioning of an enterprise and online management. However, online control mode becomes the norm. Apply the actions intended for serious critical situations (as a rule, force majeure circumstances) is inappropriate.

The emergence of new and new controls causes the need for further improvement and adaptation. At the same time, the active development of new approaches and methods of their creation are made.

Thus, the central task for online management is to form solutions and plans based on current information. In this regard, the effective solution of the problem under consideration, as well as progress in automatic control in general, can be obtained by a common information field, which is updated by the continuous monitoring system of the control object [7].

Ontology is used to describe a subject area or a specific task (Ontology in the theory of objects and their ties) [8]. The ontological approach makes it possible to describe the structure of an enterprise and its components. It is a good tool for creating a database and building a real-time control system [9], [10].

In the conditions under consideration, real-time control is necessary for an enterprise (plant, factory). However, it is also necessary for other areas of activity: service [1], trade [11], energy supply [12], transport [13], vocational education [14] and others.

Problems of the formation of continuous monitoring systems of processes occurring both in the system and in its environment were practically freed from technical and technological restrictions. Now it is basically a decision of organizational issues. Search for answers to these questions occurs when the information system of the enterprise is introduced. At the same time, complex economic, social and psychological problems arise. This is the need for a partial or complete reorganization of the enterprise structure and the need to change business technologies. The resistance of the company's employees and a number of other problems can also arise.

Because of the above, the following task is of interest to solve. The company implements an existing set of orders. At some point in time, the company receives a new proposal (order) for the supply of products described by a number of parameters: assortment, quantities, price, execution time and others. It is necessary to form a plan that is provided with resources, technology and can be implemented (permissible plan). Such a plan takes into account the interests of the enterprise, its condition and opportunities, the entire set of orders that have been taken earlier. The plan should be supplemented with performance indicators (we denote them through $\mathrm{W}$ ) to quickly take a reasonable solution.

The features of this task is as follows: 1) there are a large number of factors; 2) high degree of uncertainty in the development of the situation; 3) It is impossible to use averaged indicators and traditional planning methods (mathematical programming, probability theory).

For the sake of convenience in presenting the essence of the proposed solution to this problem, we will restrict ourselves to a number of simplifications:

- during this period, only one application for the production of one type of product is being considered;

- production is characterized by integral productivity;

- for the manufacture of a unit of production, material is used as a generalized concept;

- for each present and subsequent time intervals there is information about the available amount of material and the financial capabilities of the enterprise.

As the analysis shows, the expansion of these conditions leads to a complication of the description and to an increase in the dimension of the problem, but does not affect the essence of the proposed approaches. 


\section{CONSTRUCTIVE-SIMULATION METHOD OF PLANNING}

In the theory of decision-making, a prominent place is occupied by the tasks of modeling the activities of various kinds of organizational systems, where so-called weakly structured problems often arise. An essential feature of these problems is ignorance of the object of modeling and, as a consequence, the presence of various kinds of uncertainties that prevent the construction of formal models for describing possible trajectories of the functioning of these systems. The problems that arise when solving problems of the type formulated above are also weakly structured.

In the field of management of organizational systems, an important place belongs to the concept formulated by management, presented, as a rule, in verbal form. The idea usually includes: the main goal of the control object, a possible way to achieve it is schematically indicated, some recommendations for solving specific problems are described, and the main performance indicators are formulated. Obviously, this only determines the scheme of subsequent management actions and requires the development of a complete detailed plan for translating the idea into reality. It is desirable to accumulate such information in the knowledge base of each enterprise [15].

When planning (in the traditional sense), various mathematical models can be used, which are based on hypotheses about a specific variant of the development of situations with certain values of parameters and schemes for performing individual actions [16]. While the use of traditional mathematical methods justifies itself for forecasting and developing plans for a sufficiently long term, the situation is different for operational planning tasks. The scheme for the formation of operational decisions is usually not fixed, since it significantly depends on the developing situation. So, given the possibility of fulfilling the request, we can fulfill some part of it at the expense of stocks of finished products in the warehouse (the question is in what part?). Then the rest will need to be done specifically for this order (in what time frame, with what resources?). Since the volume of the order for the manufacture of products changes over time, you can form a large number of options for the potential activities of the production itself. The situation is similar with the expenditure of material, financial and other resources. This means a dramatic increase in the variability of production support situations.

When faced with such obstacles, very primitive balancing methods are usually used in practice. Schemes of actions of the control object, its subsystems and elements are considered fixed (guided by pre-written rules and instructions) In another case, planning is transferred to lower levels of management (departments and services) without assessing the real possibilities of production. In this case, the boss considers such tasks to be unconditionally completed (action on the principle: they must perform). Obviously, for organizational systems, this approach leads to the construction of low-quality plans, which, as the processes of interaction between business entities accelerate, become an ever greater obstacle to their successful activity. As a result, the urgency of solving the problem of providing control bodies with the possibility of operational development of detailed resource and technologically feasible plans increases, which implies a transition to fundamentally new schemes of mathematical modeling.

In practice, the manager analyzes the situation at the present time (so to speak "for tomorrow") and formulates, as a rule, very rational private solutions. This fact was adopted as a basis for the design and modeling method under consideration (CSM-method) [17].

It consists of the following cycle: 1) a description of the situation (the state of the object and the environment); 2) the formation of a complete set of potentially possible socalled private solutions; 3) the choice of one of the solutions as a fragment of the future plan; 4) modeling the execution of this particular solution as the process of transitting the modeling object to a new state. Thus, from an ordered, interconnected and interdependent set of private solutions, a general plan for achieving goals is created. Please note that the space-time process of the enterprise under consideration is the object of modeling. There are various options for modeling the activity of the enterprise. However, most of them are not suitable for online management of the production process [18].

Thus, a two-stage scheme is implemented step by step: in a given specific situation, a resource and technologically possible private solution is created and the process of its implementation is modeled. The system model is transferred to a new state. Then the cycle of forming another frequent solution and its modeling is repeated. That is why the method is called by us the constructivesimulation method (.the CSM method).

Thus, the main steps of the CSM method are as follows.

1. For the current time interval, the system generates a complete set of possible particular solutions (a set of permissible plans) for each functional component of the modeling object. If the set of permissible plans is empty, the System switches to the next time interval. The initiative to form a particular solution belongs either to another component or is contained in the conditions of the order. For example, send a finished product to a customer on a specified date.

2. Otherwise, each of the permissible plans is weighed. Weight, as usual, is designed to account for all "for" and "against" this solution. The weight $\mathrm{G}_{\mathrm{j}}$ of each $\mathrm{j}$-alternative is formed by the formula that we usually apply and recommend:

$$
\mathrm{G}_{\mathrm{j}}=\sum_{\forall h}\left(c_{h} g_{j h}\right) / \sum_{\forall r}\left(c_{r} q_{j r}\right)
$$


$g_{j h}$ is the value of the h-parameter, the increase in which as a whole corresponds to the objectives set in front of the object. This, for example, profits, product quality, company quality and much more;

$q_{j r}$ is the value of the r-parameter, the decrease in which in general corresponds to the objectives set for the system. These are the indicators: the time, the cost of the operation or product, the number of waste and the other;

$\mathrm{C}_{\mathrm{h}}, \mathrm{C}_{\mathrm{r}}$ - model setup coefficients.

For the formation of the weight $\left\{\mathrm{G}_{\mathrm{j}}\right\}$ of a private solution, corresponding cognitive cards can be used [19].

3. On the set of scales $\{\mathrm{gj}\}$ as a fragment of the formable plan, one particular solution is selected. This choice is advisable to carry out the method of a randomized draw, the scheme of which is widely used [20]. Let $\xi$ be the generated value that is equally distributed on the segment $[0,1]$ of a random variable. Then the same alternative to the alternative $\mathrm{j}^{*}$ which is the first (as $\mathrm{j}$ ) satisfies the condition

$$
j^{*}=\min \left[k \mid \frac{\sum_{j=1}^{k} G_{j}}{\sum_{j=1}^{j_{0}} G_{j}}>\xi\right],
$$

where $\mathrm{k}$ is the number of alternatives already considered, $\mathrm{j}_{0}$ is the total number of alternatives formed.

The possible critics of using such, in general, "blind" procedures explain that at least at the stage of building a model randomized draw in full alternatives are fundamentally necessary, since the elimination of any resource and technologically possible private solutions can lead (by the way, that we And we see when using other mechanisms) to an inefficient solution of the problem as a whole (a special solution with a small weight can sometimes lead to the best general solution of the task). The model setup coefficients $\mathrm{Ch}_{\mathrm{h}}, \mathrm{C}_{\mathrm{r}}$ serve for a finer account of the features of the systems under consideration or the conditions of their functioning at the operation stage.

4. The procedure for implementing a private solution is carried out after its choice. All the actions of the plan are carried out with all the components of the system. In addition, it is very important, changes to the object state are recorded at all subsequent time intervals, for example, spending and the acquisition of resources is fixed.

The solutions obtained in the considered time interval are implemented only in subsequent time intervals. This rule is practically not difficult (since the time interval can be chosen very small). This ensures the creation of private solutions that do not contradict each other. In addition, since only admissible particular solutions are formed, the decision that is selected from them can be performed unconditionally. The duration of the implementation of this solution can cover several subsequent time intervals, which is also fixed.
5. The model of the object goes into the final state (in this case, the action plan of all enterprise components for execution of the order is formed). A set of all selected private solutions forms an enterprise plan to fulfill the order. So, one of the permissible plans of the enterprise is formed. It is supplemented by the values of all indicators of the effectiveness of the enterprise. In other words, we form and implement one of the possible options for solving the problem. If the procedure for forming a plan has repeatedly repeated, then from the received set of plans you can choose the most appropriate option in the sense of the selected criterion

The longer a series of tests, the greater the likelihood of receiving the best plan. However, since in practice the number of possible options for plans is very large, significantly increased the number of tests of the model is not recommended. The so-called setting according to the criterion increases the likelihood of obtaining the best plan.

Since the operation of the randomized draw is implemented in the process of forming a plan, the production plan with a certain indicator of its effectiveness $\mathrm{W}$ is an event random. After conducting a series of tests, you can build a histogram describing the distribution of the frequency of generating a plan with different values of the criterion. This allows you to estimate the likelihood of obtaining a plan with an efficiency indicator at the specified value interval.

In the process of studying the model, it was shown that due to the selection of settings, you can deform the histogram of the distribution of plans. In this case, the probability of obtaining the optimal plan can be significantly increased.

\section{ENTERPRISE PLAN MODEL FOR ORDER EXECUTION}

We describe a simplified scheme for the formation of a permissible plan of execution by the enterprise received the order Z [21]. Let the order for the production of products (in the most simplified form) is the following vector:

$$
Z=\left(m, T_{z}\right),
$$

where $m$ is the volume of ordered products, $T_{z}$ is the time execution of the order.

It is assumed that the company is working on the fulfillment of its portfolio of orders already existing. In addition, predicting the development of the situation, the enterprise can produce products regardless of the presence of orders (work for the warehouse). For its activities, the enterprise acquires the necessary consumables, produces products, contains a certain stock of materials and finished products. All relevant information for each current day (or selected time interval) and perspectives (which are already scheduled and approved) are contained in a corporate database. For further presentation, references will be required: 
$\mathrm{n}(\mathrm{t})$ - the volume of unallocated finished products in the warehouse per day $\mathrm{t}$;

$h(t)$ - the volume of products that can make an enterprise per day $t$ (characterizes the free power of production itself);

$\mathrm{s}(\mathrm{t})$ - the volume of unallocated consumables, which has an enterprise for the day $t$;

$l(t)$ - the amount of unallocated financial resources that can be consumed by the enterprise to purchase consumables and other needs for the day t.

Managers formulate the rules for holding a client dialogue and the rules for developing an order plan.

Their actions are based on the results of work experience, on the analysis and forecasting of the development of the situation, as well as based on the set of goals. First of all, this desire to keep some resources. It is advisable to formulate the rules in accordance with which not all order is performed at the expense of products in stock; production is not used in full force; Not all materials are taken from the relevant warehouse (some of them can be purchased); Not all currently available financial resources can be spent.

Such rules can be formulated in a mild form using elements of fuzzy mathematics. For example, we can use linguistic variables and functions..

For example, $\mu_{\mathrm{i}}(\mathrm{x})$ is the function of the belonging that can describe the ability to take parts from the warehouse of finished products, guided by the following rules: if $\mathrm{I}=1$, then you can take a small part of the reserve; if $i=2$, then you can take half of the reserve; if $i=3$, you can take most of the reserve. The selection of one of these three rules can be performed in advance when setting up the model. In essence, each value of $\mu_{\mathrm{i}}(\mathrm{x})$ is a measure of expediency for accepting an i-version of actions for which the corresponding part of the finished product or consumables is taken from the warehouse $(0 \leq \mathrm{x} \leq 1)$.

Such functions are entered for all other subsystems:

$v_{i}(x)$ - the function of the belonging, which describes the feasibility of using a part of the production capacity to execute the order;

$\phi_{\mathrm{i}}(\mathrm{x})$ - the function of the belonging, which describes the feasibility to ensure the production of existing stocks of consumables;

$\varphi_{\mathrm{i}}(\mathrm{x})$ - the function of the belonging, which describes the feasibility of partial financing of the purchase of necessary materials from borrowed funds.

The choice of each next private solution is implemented on the basis of such function of the belonging.

Naturally, the formation of an order execution plan must be started with the definition of a potential opportunity to satisfy the conditions of the order. It is necessary to check the condition:

$$
\max _{t \leq \tau \leq T_{z}} n(\tau)+\sum_{\tau=t}^{T_{z}-1} h(\tau) \geq m
$$

If the condition is not fulfilled, it means that the company does not have the ability to fulfill this order. In this case, the order is rejected. Changing the stated conditions can be coordinated. This can be viewed as a formulation of a new task. The formation of the plan continues if this condition is performed. In fig. 1 is a scheme of the order execution plan.

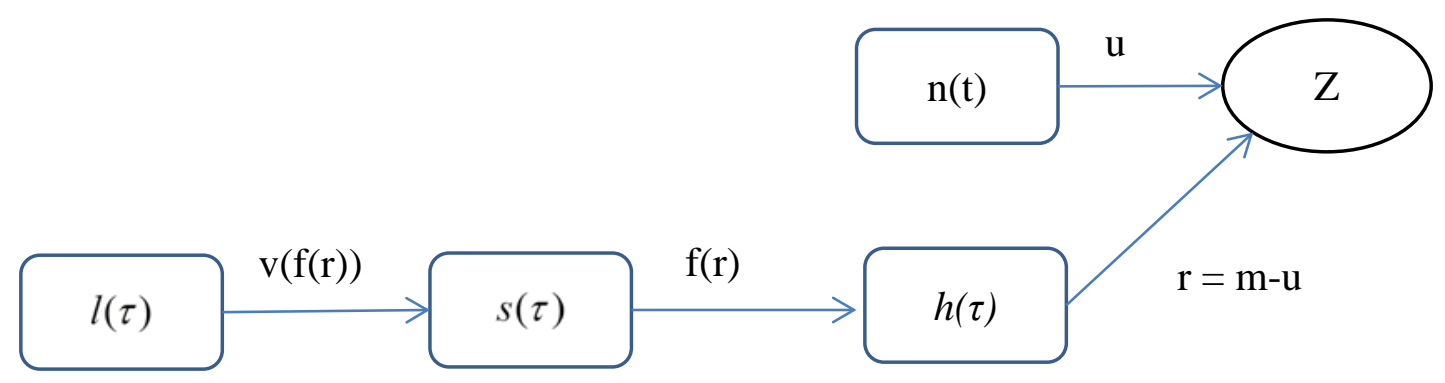

Fig. 1. Scheme of the order execution plan

Let us describe the logic for calculating the feasible plan. To do this, we will use the following idea of the CSM method: at each stage of creating a plan, we will consider a solution for only one subsystem. For example, it is necessary to decide how much of the resources can be taken from the finished goods warehouse. For these purposes, a randomized test is performed on the set of all values of the membership function $\mu_{\mathrm{i}}\left(\mathrm{x}_{\mathrm{k}}\right)$. This allows you to form a decision on the issue of finished products in the amount of $\mathrm{U}=\min \left\{\mathrm{n}(\mathrm{t}) \mathrm{x}_{\mathrm{k}}, \mathrm{m}\right\}$ units. from the warehouse. Such 
calculations can be carried out not only for the day the order is received, but also for all days in the interval. $\left[t+1, T_{z}-1\right]$.

When choosing a specific solution,

$$
\mathrm{u}=\min \left\{\mathrm{n}(\mathrm{t}) \mathrm{x}_{\mathrm{k}}, \mathrm{m}\right\},
$$

the rest of the order in the amount of $r=(m-u)$ units should be performed due to the production itself. Obviously, this can be implemented, for example, for several days of production. What and how many products do in each of them? It is clear that the extraction days should be placed in the interval $\left[t+1, T_{z}-1\right]$, where the condition is recorded that the results of production can be issued to the client, for example, the day after their production. Determining how many units of products and what day should be done to execute an order is carried out at two stages. Initially, one of the arguments of the function of the belonging $v_{i}\left(x_{k}\right)$ is selected, which determines which part of the free power can be used, that is, $\mathrm{x}_{\mathrm{k}}$. Previously received orders remain in the plan of the enterprise. Then day $\tau$ is selected from the interval $\left[t+1, T_{z}-1\right]$. For the selected day, the production volume is recorded, which is designed to perform orders, in the amount of $\mathrm{r}_{\tau}=\min \{\mathrm{h}(\tau)$ $\left.\mathrm{X}_{\mathrm{k}}, \mathrm{r}\right\}$ units. After that, the solution must be fixed:

$$
\mathrm{P}(\tau)=\mathrm{r}_{\tau} ; \mathrm{h}(\tau)=\mathrm{h}(\tau)-\mathrm{r}_{\tau} .
$$

Then $\mathrm{R}=\mathrm{R}-\mathrm{R} \_\tau$ and the procedure described continues, and until the condition $\mathrm{R} \_\tau=0$ is executed. In the end, we get many plans for production in the interests of the order under consideration:

$$
\mathrm{P}(\tau) \forall \tau \in\left[\mathrm{t}+1, \mathrm{~T}_{\mathrm{z}}-1\right]
$$

Consumables are needed for planned production. The determination of which volume of materials take from the warehouse of materials, and which is purchased on the market, it is proposed to be carried out according to a similar scheme, but taking into account the time required to deliver purchased materials. Similarly, the question of financing can be solved.

The procedure described forms an enterprise action plan (its main divisions) to fulfill the order::

$$
\mathrm{P}_{\mathrm{z}}=\left\{\mathrm{u}\left(\mathrm{T}_{\mathrm{z}}\right), \mathrm{P}(\tau), \mathrm{P}_{\mathrm{s}}(\tau-1), \mathrm{P}_{\mathrm{l}}(\tau-\alpha)\right\}
$$

for all $\tau \in\left[\mathrm{t}+1, \mathrm{~T}_{\mathrm{z}}-1\right]$.

Here $\mathrm{P}_{\mathrm{s}}(\tau-1)$ and $\mathrm{P}_{1}(\tau-\alpha)$ are fragments of the plan for the activities of the warehouse of materials and financial bodies, respectively, $\alpha$ is the time interval necessary for the procurement of materials.

It should be noted that the formed plan is always a permissible plan, therefore the procedure for its formation occupies a central place in the decisions on the management of the enterprise from the point of view of orders.

\section{CONCLUSION}

New business technologies require fast planning and enterprise management tools. The considered method uses a production model. This allows you to take into account the resources of the enterprise, the orders received and the possible time frame for the fulfillment of these orders. The changing database of the enterprise provides the ability to quickly get a permissible plan, that is, a plan that is provided with resources, technologies and can be implemented. Such plans are the basis for fulfilling contractual obligations. The method described in the article allows us to hope for the practical effectiveness of such a control technology.

\section{REFERENCES}

[1] Новаторов В.Е. Кастомизация товаров и услуг в маркетинговой деятельности // Маркетинг услуг. 2014. № 3. С. 228-235.

[2] Боркова Е.А., Носкова П.О. Современное развитие рынка электронной торговли в макроэкономических условиях России // Российское предпринимательство. 2019. - Том 20. - № 4. - С. 917-926

[3] Бочкова Е. В., Кузнецова С. Д. Перспективы и применение технологии blockchain в современном мире // Научно-методический электронный журнал «Концепт». - 2017. - T. 39. - С. 3436-3440. - URL: http://e-koncept.ru/2017/971014.htm.

[4] Трунцевский Ю. В., Севальнев В. В. Смарт-контракт: от определения к определенности // Право. Журнал Высшей школы экономики. 2020. № 1. С. 118-147. DOI: 10.17323/2072-8166.2020.1.118.147

[5] Асланова И.В. MES как основа разработки систем управления производственными процессами предприятия // Российское предпринимательство. 2017. T. 18. № 11. С. 1651-1658.

[6] Ощепков В.М., Лохматова В.А. Проблемы внедрения ERP на предприятиях // Научное обозрение. Экономические науки. - 2019. - № 2. - С. 44-48

[7] Конноли Т., Бегг К. Базы данных. Проектирование, реализация и сопровождение. Теория и практика. - М.: Издательский дом "Вильяме", 2003. - 1440 с

[8] I. Antonov, I. Bruttan, D. Andreev, and L. Motaylenko, "The method of automated building of domain ontology," in Environment. Technology. Resources: Proceedings of the 12th International Scientific and Practical Conference on Information Technologies, Rezekne, 2019, vol. II, pp. 34-37.

[9] D. Andreev, S. Lyokhin, L. Motaylenko, and S. Verteshev, "Models and algorithms for constructing a formalized description of production technologies," in Environment. Technology. Resources: Proceedings of the 12th International Scientific and Practical Conference on Information Technologies, Rezekne, 2019, vol. II, pp. 21-27.

[10] D. Andreev, S. Lyokhin, V. Nikolaev, and O. Poletaeva, "Development of software for design ontological representations of production technologies," in Environment. Technology. Resources: Proceedings of the 12th International Scientific and Practical Conference on Information Technologies, Rezekne, 2019, vol. II, pp. 28-33.

[11] Архипова Надежда, Гуриева Мадина Современные тенденции развития цифрового маркетинга // Вестник РГГУ. Серия «Экономика. Управление. Право». 2018. 
№1

(11).

URL:

https://cyberleninka.ru/article/n/sovremennye-tendentsii-

razvitiya-tsifrovogo-marketinga.

[12] A. Verteshev, S. Verteshev, O. Timofeeva, and D. Andreev, "Rational power supply of energy-deficient regions," in Environment. Technology. Resources: Proceedings of the 12th International Scientific and Practical Conference on Environment and Resources, Rezekne, 2019, vol. I, pp. 325329.

[13] Алексеев А.И. Анализ информационных технологий, используемых в логистике // Инновационная наука. 2016. №12-1. URL: https://cyberleninka.ru/article/n/analizinformatsionnyh-tehnologiy-ispolzuemyh-v-logistike.

[14] Искрин Никита Сергеевич, Чичканова Татьяна Анатольевна Менеджмент в образовании: системный подход // Образование и наука. 2015. №1 (120). URL: https://cyberleninka.ru/article/n/menedzhment-vobrazovanii-sistemnyy-podhod.

[15] Daniel Abadi, Alexander Thomson. The Case for Determinism in Database Systems. 36th International Conference on Very Large Data Bases, September 13-17, 2010, Singapore. Proceedings of the VLDB Endowment, Vol. 3, No. 1, 2010, pp. 70-80

[16] Закорюкина А.В. Анализ и оптимизация управленческих решений в процессе бизнес- планировании. //Эффективные системы менеджмента: качество, инновации, устойчивое развитие Т.1, №4, 2014. C 29-35.

[17] Воронов М.В. Конструктивно-имитационное моделирование слабоструктурированных систем //Известия МАН ВШ, №4(42). 2007. С.156-165.

[18] Крышень Е.В., Лаврусь О.Е. Моделирование производственных процессов // Известия Самарского научного центра Российской академии наук, т. 14, №4, 2012.-.C. 209-302

[19] Авдеева З.К. Когнитивный подход в управлении // Проблемы управления - -№3. 2007. - С. 2-8.

[20] Гасников А.В., Двуреченский П.Е., Усманова И.Н. О нетривиальности быстрых (ускоренных) рандомизированных методов // Труды Московского физико-технического института (национального исследовательского университета). 2016. Т. 8. № 2 (30). C. 67-100.

[21] Воронов М.В., Аладко А.В. Модель оперативного планирования деятельности предприятия // Моделирование и анализ данных. МГППУ, №1, 2016. С. 37-47. 